\title{
Attention and Meaning in the Democratic Group Life
}

\author{
Ruth Yeoman \\ Fellow, Kellogg College, University of Oxford, Oxford, UK \\ ruth.yeoman@kellogg.ox.ac.uk \\ Associate Professor of Business Ethics, Northumbria University, \\ Newcastle, UK \\ ruth.yeoman@northumbria.ac.uk
}

\begin{abstract}
Bringing Simone Weil into conversation with Roberto Frega's Pragmatism and the Wide View of Democracy
\end{abstract}

\section{Keywords}

democracy - attention - meaningfulness - power

We live in an era of complex inter-dependence. This renders us vulnerable to planetary-scale risks arising from technological change, climate heating, biodiversity collapse, and is now - painfully - confronting us with new zoonotic diseases that are rocking the foundations of our global order. We are being forced to reflect upon our social, economic, and political organisation: what and who we value, and how we organise to care for those beings and things that bring meaning to our lives. Even more urgently, we have become acutely aware that without those willing to work in the caring and provisioning economies - and during the Covid-19 crisis to put themselves in harm's way for our sake - human civilisation cannot be maintained upon the earth.

A revival of the ideal of democracy as a way of life is therefore timely, and Roberto Frega's proposal to extend the scope of democratic organisation to all varieties of associations is welcome. In his formulation, the normative value of democracy derives from the opportunities that democratic organisation 
affords for the moral development, collective learning, and social progress of as many people as possible, extending to all those affected by the activities of the organisations that shape their interactions. Frega's wide view of democracy therefore offers us valuable resources for specifying ethically desirable forms of organising that can help us to address the sustainability imperative. Such forms of organising will be directed to re-ordering our ways of life, including our patterns of interaction with one another and the natural world, so as to maintain human civilisation within planetary boundaries. In particular, Frega's democratic principles of relational parity, inclusive authority, and social involvement mediate the formation of collective capabilities for knowing and creating our world as a habitation of mutually inter-dependent beings and things, thereby equipping us to accept responsibilities to care and to steward. By applying Frega's wide view of democracy to the expanse of organised life, we can bring forward resources for a total learning system that is grounded in a consciousness of our shared fate - a consciousness that is foundational for planet-spanning social cooperation.

Democratic political theory has not had much to say about the status of organisations, or the associational ecosystems of which they are a part. Despite notable exceptions such as Paul Hirst's Associative Democracy, organisations have been marginalised as moral-free sites or political voids that, although externally regulated by political institutions, are not conducive to emancipatory political action - for example, through the democratic organisation of work (Hirst, 2007). This neglect has recently been remedied by theorists who are reconsidering the nature of the firm, of work, and of human organising in general (see, for example, Anderson (2017), Herzog (2017, 2018), Yeoman (2020), Singer (2018), Ciepley (2013)). When brought together with Frega's wide view of democracy theory, these scholars provide tools for developing a more complete political theory of democratically organised associational life. In my own work (see Yeoman, 2020), I characterise all organisations - whether or not they are democratically organised - as associational ensembles of beings and things towards which we have responsibilities of care. Often, these beings and things are of independent moral significance, and we attach ourselves to them to the extent that they give us a sense that our lives are worth living, or are meaningful (Yeoman, 2014a; 2014b). With this in mind, I argue that one of the purposes of democratically organised associational life is to create a total learning system that sensitises people to their responsibilities to look after the valuable beings and things that we orchestrate into associational ecosystems, and with which our lives are intertwined. Creating assemblages under an ethic of care means bringing objects into focus as a matter of common concern - a process in which all those who are affected by how well the object is doing have an interest. Pettit (2014) describes collective entities as 'a group whose 
members combine to act within group roles in such a way that the group as a whole simulates or mimics an individual agent' (p. 1641), where collective agency is maintained by the actions of members as 'attempts by the group to satisfy its purposes'. When democratically organised, collective entities are problem-solving devices for people to pursue purposes that matter to them, including especially those related to caring for the valuable beings and things that give meaning to their lives. This problem-solving function extends to networks of heterogenous entities, or the associational ecosystems constituted by interconnected and interacting beings and things that make technological human civilisation possible.

Frega's theory helps us formulate the developmental possibilities afforded by democratically organised problem-solving. I focus on one aspect of Frega's work - his use of Hannah Arendt (1958) and Mary Parker Follett (1918 [1998]) in the construction of collective power. I join Arendt and Follett with Simone Weil, one of the few philosophers of work with direct experience of factory life. I make use of Weil's concept of attention to highlight some neglected aspects of power that are relevant to enhancing Frega's project. In Frega's theory of democratic collective action (p. 161), political activation occurs within the specification and pursuit of collectively defined goals. He draws from Follett's processual and interactional perspective upon political action to identify group activity as 'an embedded dimension of social life' (p. 166). Follett creates publics out of group-based politics through the application of a 'basic grammar of democratic group activation' (p. 162) that includes an evaluation of 'consequences, conflict, interests, means-end rationality, and organizational constraints' (p. 162). For Follett, the purpose of democratic group process is integrative problem-solving where difference-generating social interaction produces inclusive, dynamic, and creative group life: 'the problem of democracy is how to make our daily life creative' (p. 171) and 'the core of the group process is creating' (p. 173). Acting as a group means: firstly, respecting deliberative principles of common reasoning, and secondly, orienting group activity towards 'the cooperative formulation and achievement of a common goal' (p. 172). The democratic group life is thus a collaborative inquiry that applies difference-making and truth-seeking to the search for means and ends which constitute normatively viable responses to contentious and intractable problems. Consistent with Frega's democratic principles, the capacity of the group to act is augmented by including - under relational conditions of equality and mutual respect - as many people as possible in crafting solutions to shared problems.

Group life is maintained when the group has the ability to create collective power (p.319). In Arendt's theory of communicative power, power is the 'power to begin', 'to act in concert', where practices of 'binding and promising, combining and covenanting are the means by which power is kept in 
existence' (Arendt, in Frega, p. 323). Collective power is produced when people act together, and as a property of the group endures only so long as the group endures. Arendt is sceptical of using bureaucratic organisation to extend the duration of collective power. She sees bureaucracy as a form of tyranny that eliminates responsible agency. By contrast, Follett's concept of coactive power, or power-with (p. 324) - which privileges integration over coercion and bargaining in decision-making - is manifested and maintained within an institutional infrastructure: 'rather than power to begin, power with is the power to create, to innovate in the face of uncertainty and of the problems which a social unity - not matter which - has to face' (p. 326). For Follett, the site of action is not politics as a realm unsullied by bureaucratic administration, but rather resides in the processes of human interaction that emerge in organisations and associations, and between 'individuals who submit to a common destiny and must act together' (p. 325). Frega summarises:

'[...] whereas for Arendt communicative power can be grasped only against the background of the irreducible alterity of political action and everyday praxis, for Follett power with exists only when self-government is combined with successful functional differentiation, which means when authority and responsibility are distributed according to capacities' (p. 325).

The purpose of collective power is to help us look after beings and things that matter to us. This is because valuable beings and things that make our lives worth living often present us with problems which can be dealt with only through associational organising. Solving such problems invariably involves practical reasoning regarding what these objects mean to us ('ends'), and how they can be cared for ('means'). Arendt and Follett, supplemented by Weil's insights regarding the practice of attention, offer resources for means/ends practical reasoning in group life that is directed towards caring for objects of common concern. A neglected aspect of practical reasoning is our need for meaning in life and work, and the role that the moral value of meaningfulness plays in motivating collective action (Yeoman, 2020). We reason together regarding what we ought to do to take care of those beings and things that possess independent moral significance and to which we are emotionally attached and involved (Yeoman, 2014a; cf. Wolf, 2010). Our vulnerability to harms that may be done to these being and things stimulates collective action, often resulting in enduring forms of organisation. Wallace (2006) identifies a mode of reasoning that he calls 'eudaimonistic reflection', which involves asking 'whether engaging in these pursuits is worthwhile, something that makes 
our own lives choice-worthy as human lives' (p. 395). Wolf (2010) describes meaningfulness as a moral value distinct from utility or virtue that combines the objective/ethical-normative and subjective/cognitive-emotional dimensions. In collective deliberation regarding means and ends, participants in group life derive objective and subjective dimensions of meaningfulness from people, projects, and other things, and incorporate these dimensions into collective practical reasoning concerning what they ought to do. Practical reasoning focussed upon the welfare of valuable beings and things is enhanced when groups adopt practices of attention to surface and interpret the meanings implicated in objects of shared concern, and to carry ethically viable meanings forward into collective understanding and knowledge building.

Making the object visible as a matter of common concern, so that groups can create collective purposes directed at caring for that object, entails interactive processes of meaning-making. The multiple, and often conflicting, perspectives afforded by democratic organisation reveals objects as plural entities, enmeshed in relational webs, and constituted by meanings. Under the relational conditions provided by Frega's three principles, these meanings can be translated into the understanding and knowledge needed for collective learning. Arendt (1954) connects meaning-making to the understanding and knowledge needed for means/ends reasoning in collective action: 'understanding is based on knowledge and knowledge cannot proceed without a preliminary, inarticulate understanding' (Arendt, 1954: p. 310). When faced with perplexing situations, inclusive participation in group life, under conditions of mutual respect and equal interactive status and power, can help people use meaning-making to bridge knowledge and understanding. In the absence of meaning-making, there are 'only events and no meanings' (Hansen, 2004: 7), and life becomes 'dumb, preposterous, destructive' (Dewey, 1922: 280). Frega's three principles specify what structure action contexts need to have if interactions between self, others, and objects are to generate productive cycles of meaning, knowledge, and understanding. In problematic situations, these mediated interactions of meaning-making are a source of interpretive differences that outline the horizon of shared understanding. By incorporating the value of meaningfulness into practical reasoning, groups can expand this preliminary understanding to enrich knowledge with diverse meanings (Arendt, 1954: p. 311); evaluate judgments and assumptions; and 'prepare a new resourcefulness of the human mind and heart' (ibid: p. 310).

By investigating the meanings implicated in problematic situations, groups construct the understanding and knowledge they need to sustain what they value, and to make the world into a home where they can dwell together with 
the beings and things that matter to them: 'For you will have developed a frame of mind which gives meaning to things that happen; and to find a meaning, to understand along with others, is always a contentment, an enjoyment' (Dewey, 1922: p. 279). Meanings are generative of purpose as the ends of collective organising. Follett links meanings to purposing in a processual view of ends, such that 'ends and meanings truly and literally make each other' (Follett, 1919: p. 579). Follett (1949) argues that participants in group life create and recreate purpose through integrative social processes that engage all those participating in collective action around a matter of shared concern. She critiques 'teleological psychology' (p. 33) for fixing purposes prior to action, thereby submitting relational processes to pre-determined ends: 'no more fatally disastrous conception has ever dominated us than the conception of static ends' ( $p$. 33). There are no already extant purposes waiting to be discovered, since 'purpose is not 'preexistent, but involved in the unifying act which is the life process. It is man's part to create purpose and to actualize it' (Follett, 1919: p. 578).

Practices of attention help people form collective perceptions of diverse meaning-sources - cultural, historical, economic, moral, and more. When filtered through the value of meaningfulness, these meaning-sources provide symbolic cognitive-emotional material for means/ends reasoning, and hence the co-creation of purposes. McGilchrist (2019) describes attention as a dynamic, world-forming cognitive function, such that 'attention changes what kind of thing comes into being for us, in that way it changes the world' ( $p$. 28). This capacity can be augmented by Weil's concept of attention, for whom attention is a feature of moral agency that has potential to actualise human freedom in the midst of acting together. Although not explicitly connected to her thoughts on collective action, Weil's concept of attention has much to offer a theory of democratically organised group life. For Weil, free action lies in the continual re-creation of the self through transformative processes of action. She argues that collective reasoning and planning make problems susceptible to human action, and that by constantly turning constraints into actionable obstacles, the individual continually re-constitutes himself: 'A completely free life would be one wherein all real difficulties presented themselves as kinds of problems, wherein all successes were as solutions carried into action' (Weil, 1955 [2001]: p. 68; see also Weil (1946 [1977]). With this in mind, Weil finds emancipatory moments of collective agency that are potent with possibilities for individual development even within intensively divided factory work:

'.... a team of workers on a production-line under the eye of a foreman is a sorry spectacle, whereas it is a fine sight to see a handful of workmen in the building trade, checked by some difficulty, ponder the problem 
each for himself, make various suggestions for dealing with it, and then apply unanimously the method conceived by one of them, who may or may not have any official authority over the remainder. At such moments the image of a free society appears almost in its purity' (WEIL, 1955 [2001]: p. 95).

Weil describes attention upon the object as a suspension (but not an absence) of thought that leaves our minds detached and ready to be influenced by the object. As our awareness opens out to the object, we hold onto our diverse but provisional knowledge about the object lightly, thereby making ourselves willing to have that knowledge amended.

'[...] holding in our minds, within reach of this thought, but on a lower level and not in contact with it, the diverse knowledge we have acquired which we are forced to make use of. Our thought should be in relation to all particular and already formulated thoughts, as a man on a mountain who, as he looks forward, sees also below him, without actually looking at them, a great many forests and plains. Above all our thought should be empty, waiting, not seeking anything, but ready to receive in its naked truth the object that is to penetrate it.' (WEIL, 1966 [2010]).

Murdoch describes Weil's attention as 'a just and loving gaze directed upon an individual reality' (in Cordner, 2016: p. 199). As a moral ability, attention is a pathway for moral learning: 'moral change comes from an attention to the world [...] through an increased sense of reality, primarily of people, but also of other things' (Murdoch, in Cordner, 2016: p.206). Weil's concept of attention involves receptiveness to different ways by which the object of attention reveals itself. So, not merely receiving the object by weighing and judging at a distance, but being influenced by seeing: 'attention as a kind of receptiveness, and as accompanying, being present at or to, waiting on, serving, answering to' (Cordner, 2016: p. 208). Rather than hiding oneself from the other, attention involves letting oneself be seen. Mutual visibility to one another entails mutual vulnerability to be changed by that seeing. By fostering receptivity to other beings and things, and discovering that they have an independent reality, we are formed and changed by our appreciation and acknowledgement of another's distinct existence. When adopted in democratically organised group life, attention fosters processes of knowing that extend the possibility of self-transformation through a willingness to be shaped by the object. This kind of attention involves orientations of 'waiting', rather than 'searching', through which we forge an understanding of the 
object with our 'whole selves'. This is an indirect method of knowing the object which avoids excessive or dysfunctional attachment that may work against the welfare of the object (and ourselves). Attention is particularly important when caring for others - Weil (1966 [2010]) says that giving attention to someone who is suffering is 'a very rare and difficult thing; it is almost a miracle' (p. 36). She continues:

'The love of our neighbour in all its fullness simply means being able to say to him: 'What are you going through?' It is a recognition that the sufferer exists, not only as a unit in a collection, or a specimen from the social category labeled 'unfortunate', but as a man, exactly like us, who was one day stamped with a special mark by affliction. For this reason it is enough, but it is indispensable, to know how to look at him in a certain way. [...] This way of looking is first of all attentive. The soul empties itself of all its own contents in order to receive into itself the being it is looking at, just as he is, in all his truth. (WEIL, 1966 [2010]: p. 36)

Weil says that attention entails a process of de-creation: the destruction of the 'I', or the ego which focusses attention solely upon itself. Freeman (2015), however, is concerned that thinking of attention this way entails self-annihilation. He interprets attention as a 'holding-in-abeyance' (p. 165) that fosters 'a kind of full emptiness' (p. 165), or a sensitive perception of the separateness and difference of the object, whilst recognising mutual connectedness. In other words, attention operates in the gap between separation and joining. Attention helps relate us to valuable beings and things through interactions of simultaneous alienation and reconciliation that provide space for the exploration of meanings. Moreover, attention stimulates generosity and capaciousness in meaning-making when collective processes of meaning-making are structured by Frega's three democratic principles of interaction. Openness to diversity and difference yields ethically viable meanings that can be carried forward into shared understanding, collective knowledge building, and joint learning.

When attention is practised in group life that is organised by Frega's three principles, participants are more equipped to service one another with acts of caring concern: 'love is the deep knowledge of the individual' and 'a deepening process $[\ldots]$ an altering and complicating process' (Murdoch, 2001: p. 425). Millgram describes the ability to see things and beings with attentive love as 'an arresting awareness of value in a person that makes one really see him or her' (in Cordner, 2016: p. 202). How to re-conceive the value of beings and things is an urgent undertaking for our times. Putting attention to work 
upon the means/ends needed to care for valuable beings and things sensitises groups to what is of value, and builds up structures of value around about us' (Murdoch, 2001: p. 429). A group capability for attention in democratically organised collective action stimulates what Murdoch describes as descriptivenormative talk in the presence of the common object. Democratic pathways allow such talk, in the form of narratives, ideas, words and concepts, to flow through the group life of the organisation, as well as between the organisation and other collective entities in its associational ecosystem: 'words are the most subtle symbols which we possess and our human fabric depends upon them. The living and radical nature of language is something we forget at our peril' (Murdoch, 2001, p. 427). Words are bearers of meanings that contribute to life and work meaning. Indeed, Repp (2018) argues that a meaningful life depends upon a life rich in sign meaning.

Practising attention in collective practical reasoning surfaces and augments meanings, making them available for co-creating understanding and knowledge needed to look after objects for the sake of which collective power exists. But such meaning-talk requires other modes of power in addition to collective power. Cordner (2016) is concerned that attention facilitates exploitative appropriation of the object by the efficient acquisition of critical knowledge grasping the object as an act of possession, or knowing the object so as to more efficiently pursue exploitation of the object. Allen (1998) describes power as 'the ability of a collectivity to act together for the attainment of a common or shared end or series of ends', where power-with is 'a collective ability based in receptivity and reciprocity that characterize relations among members of the collective'. But even coactive power can act against the interests of some participants who are vulnerable exploitation by failing to clear our 'distorted vision' (Murdoch, 2001: p. 429). Along with co-active power, a different kind of power is needed: one that enables us to incorporate objects into collective action using ways of knowing and seeing that put us in proper relation to those objects. This power is a form of mutual influencing - neither coactive nor coercive - but is rather the power to be open to the influence of another, as a kind of moral capacity that renders us willing to be changed by that encounter (Loomer, 1976). In Frega's approach to collective power, Arendt's coactive power - otherwise fleeting and episodic - endures within Follett's democratically organised self-governance. However, the mutual vulnerabilities involved in the practice of attention requires this other kind of power - a form of power as opening up rather than closing down, of making oneself available to become something different as a result of encountering the object. Loomer (1976) identifies this power with mutual influence, or a moral capacity of attending to, a 
readiness or preparedness to not just shape, but also to be shaped by the other, or those objects that are permanently contestable, and only temporarily fixed. This form of relational power, when organised under the principles of the wide view of democracy, facilitates the practice of attention in group life.

Relational power as mutual influencing underpins public arenas inside and between - all kinds of associations, whether these are private, public, or civic. Frega argues that Arendt's conception of the public sphere confines communicative acts within its boundaries, and therefore a broadening and pluralising of the public sphere is required. Given this, we should foster 'a plurality of heterogeneous public arenas [...] where individual and collective actors gather and struggle around a plurality of issues, only a fraction of which can be accounted for in terms of their communicative power' (p.333). We can use Frega's principles of democratic organisation to establish public arenas within and between the organisations that make up our associational life, whilst at the same time recognising that organisations are many worlds, or ensembles of valuable beings and things. For Arendt (1958), the world has a dual objective and inter-subjective character: firstly, the 'objective public in-between' of things that connect and separate human beings, and secondly, the intersubjective web of relationships that encompasses 'innumerable perspectives' (Breen, 2009: p. 142). We can surface and augment the meanings invested in these congregations of beings and things through the normative-descriptive talk that comes with the practice of attention. By such means, we grow into understanding how we are interdependent with other beings and things, and how we are made vulnerability by changes to their condition. The poet, Mary Oliver, says 'to pay attention, this is our endless and proper work'. In complex organisational ecosystems, such as supply chains, multi-stakeholder initiatives, cites and city regions, sectors and associational ensembles of all kinds, meaning-rich talk is often facilitated by boundary workers, who have special responsibility for binding together overlapping and inter-connected worlds. Many people now find themselves engaged in such boundary work, stitching public arenas into an associational fabric that has become planet-spanning. Consequently, pluralised action contexts are starting to emerge, through which people can collectively discharge their responsibilities to care for valuable beings and things. When supplemented by the practice of attention, Frega's principles for democratic associational life ensure such action contexts embody patterns of interaction between beings and things that are responsive to how all participants are affected by a world undergoing radical change. 


\section{References}

Allen, A., 1998. Rethinking Power. Hypatia, 13(1), 21-40.

Anderson, A. (2017). Private Government: How Employers Rule Our Lives (and Why We Don't Talk About It). Princeton, NJ: Princeton University Press.

Arendt, H. (1954). Understanding and Politics (the Difficulties of Understanding). In: Essays in Understanding 1930-1954. New York: Harcourt Brace and Company, 1994, 307-327.

Arendt, H. (1958). The Human Condition. Chicago \& London: University of Chicago Press.

Breen, K. (2009). Agonism, Antagonism and the Necessity of Care. In: Schaap (ed.). Law and Agonistic Politics. Surrey, UK: Ashgate, 133-146.

Cordner, C. (2016). Lessons of Murdochian Attention. Sophia, 55: 197-213

Ciepley, D. (2013). Beyond Public and Private: Toward a Political Theory of the Corporation. American Political Science Review, 107 (1), 139-158.

Dewey, J. (1922). Events and Meanings. In: Jo Ann Boydson (ed.), Essays on Philosophy, Education, and the Orient 1921-1922, the Middle Works of John Dewey 1899-1924, Vol. 13. Carbondale: Southern Illinois University Press, 1988, 276-280.

Follett, M-P. (1919). Community is a Process. Philosophical Review, 28 (6), 576-588.

Follett, M. P. (1949). Creative Experience. Peabody, MA: Martino Fine Books.

Follett, M. P. (1918 [1998]). The New State: Group Organization the Solution of Popular Government. Pennsylvania: Pennsylvania State University Press.

Freeman, M. (2015). Beholding and Being Held: Simone Weil, Iris Murdoch, and the Ethics of Attention. The Humanistic Psychologist, 43: 16o-172.

Hansen, D. T. (2004). John Dewey's Call for Meaning. Education and Culture, 20 (2): 7-24.

Herzog, L. (2017). No Company Is an Island: Sector-Related Responsibilities as Elements of Corporate Social Responsibility. Journal of Business Ethics, 146 (1): 135-148.

Herzog, L. (2018). Reclaiming the System: Moral Responsibility, Divided Labour, and the Role of Organizations in Society. Oxford: Oxford University Press.

Hirst, P. (2007). Can Associationalism Come Back? Critical Review of International Social and Political Philosophy, 4 (1): 15-3.

Loomer, B. (1976). Two Conceptions of Power. Process Studies, 6 (1), 5-32.

McGilchrist, I. (2019). Ways of Attending: How Our Divided Brain Constructs the World. London and New York: Routledge.

Murdoch, I. (2001). The Idea of Perfection. In: Millgram (ed.), Varieties of Practical Reasoning. Cambridge, MA, \& London: MIT Press, 403-436.

Pettit, P. (2014). Group Agents are Not Expressive, Pragmatic or Theoretical Fictions. Erkenntnis, 79 (S9): 1641-1662.

Repp, C. (2018). Life Meaning and Sign Meaning. Philosophical Papers, 47 (3): 403-427. 
Singer, A. A. (2018). The Form of the Firm: A Normative Political Theory of the Corporation. New York: Oxford University Press.

Wallace, J. (2006). The Rightness of Acts and the Goodness of Lives. In: Wallace, Pettit, Scheffler \& Smith (eds.), Reason and Value: Themes from the Moral Philosophy of Joseph Raz. Oxford: Oxford University Press, $385^{-411 .}$

Weil, S. (1946 [1977]). Factory Work. In: Panichas (ed.), The Simone Weil Reader. New York: David McKay Company.

Weil, S. (1955 [2001]). Oppression and Liberty. London: Routledge Classics.

Weil, S. (1966 [2010]). Waiting on God. Abingdon \& New York: Routledge.

Wolf, S. (2010). Meaning in Life and Why It Matters. Princeton, NJ: Princeton University Press.

Yeoman, R. (2014a). Meaningful Work and Workplace Democracy: A Philosophy of Work and a Politics of Meaningfulness. London: Palgrave Macmillan.

Yeoman, R. (2014b). Conceptualising Meaningful Work as a Fundamental Human Need. Journal of Business Ethics, 125 (2): 235-251.

Yeoman, R. (2020). Ethics, Meaningfulness, and Mutuality. London: Routledge Studies in Business Ethics. 